University of Nebraska - Lincoln

DigitalCommons@University of Nebraska - Lincoln

\title{
Plumage Changes in Double-crested Cormorants (Phalacrocorax auritus) Within the Breeding Season: the Risks of Aging by Plumage
}

\author{
Jennifer E. Chastant \\ Mississippi State University, j.e.chastant@gmail.com \\ D. Tommy King
}

USDA APHIS Wildlife Services, tommy.king@aphis.usda.gov

Follow this and additional works at: https://digitalcommons.unl.edu/icwdm_usdanwrc

Part of the Life Sciences Commons

Chastant, Jennifer E. and King, D. Tommy, "Plumage Changes in Double-crested Cormorants (Phalacrocorax auritus) Within the Breeding Season: the Risks of Aging by Plumage" (2018). USDA National Wildlife Research Center - Staff Publications. 2189.

https://digitalcommons.unl.edu/icwdm_usdanwrc/2189

This Article is brought to you for free and open access by the U.S. Department of Agriculture: Animal and Plant Health Inspection Service at DigitalCommons@University of Nebraska - Lincoln. It has been accepted for inclusion in USDA National Wildlife Research Center - Staff Publications by an authorized administrator of DigitalCommons@University of Nebraska - Lincoln. 


\title{
Plumage Changes in Double-crested Cormorants (Phalacrocorax auritus) Within the Breeding Season: the Risks of Aging by Plumage
}

\author{
Jennifer E. Chastant ${ }^{1,3, *}$ and D. Tommy King ${ }^{2}$ \\ ${ }^{1}$ Department of Wildlife and Fisheries, Box 9690, Mississippi State University, \\ Mississippi State, Mississippi, 39762, USA
}

\begin{abstract}
${ }^{2}$ U.S. Department of Agriculture/Animal and Plant Health Inspection Service/Wildlife Services, National Wildlife Research Center, P.O. Box 6099, Mississippi State, Mississippi, 39762, USA

${ }^{3}$ Current address: Palm Beach County Environmental Resources Management, 2300 Jog Road, West Palm Beach, Florida, 33411, USA
\end{abstract}

*Corresponding author; E-mail: j.e.chastant@gmail.com

\begin{abstract}
Scant attention has been given to the molting patterns of known-age Double-crested Cormorants (Phalacrocorax auritus). In general, subadult individuals are identified with a tan, buffy or mottled chest, and adults are identified with a black chest. While studying Double-crested Cormorant population dynamics in Ontario, Canada, with known-age birds, it was noted that the plumage of many (>75\%) breeding adults changed from black to heavily mottled during the course of the breeding season. No pattern with age was observed; plumage changed in equal proportions for all ages from 2-year-olds to 7-year-olds. A similar but reverse pattern has been observed with Double-crested Cormorants roosting at sites in the southeastern USA during fall migration. Whereas the majority of the roost had juvenile/subadult plumage in September, by mid-January the roost had shifted to $75 \%$ adult black plumage. The mechanism behind the plumage change is unknown, but extreme caution is advised when using plumage to age cormorants, especially during the winter months. By describing our observations with Doublecrested Cormorants, we hope to encourage future formal research on within-season plumage changes. Received 31 August 2017, accepted 5 November 2017.
\end{abstract}

Key words.- - adult plumage changes, Great Lakes region, juvenile plumage, molting patterns, plumage aging, plumage characteristics.

Waterbirds 41(3): 316-321, 2018

The ability to age an individual in birds can enhance ecological studies such as population demographics and reproductive biology. Plumage characteristics can be of particular importance to avian researchers. For example, studies with Double-crested (Phalacrocorax auritus; King et al. 1995), Great ( $P$. carbo; Galvan 2004), Pelagic (P. pelagicus; Filardi and Rohwer 2001) and Olivaceous ( $P$. olivaceus; Morrison et al. 1978) cormorants as well as Rock ( $P$. magellanicus; Rasmussen 1987) and Red-legged (P. guimardi; Rasmussen 1988) shags were all conducted under the assumption that individuals can be aged using plumage alone.

Double-crested Cormorant (hereafter, cormorant) plumage has been loosely described as "Juvenile", "Immature-Subadult (Basic and Alternate I and II)", and "Preand Post-breeding Adult (Definitive Basic and Alternate)" (Johnsgard 1993; Dorr et al. 2014). Juvenile plumage is inconsistent, but the head is usually a dark brownish gray to pale brown; the throat and foreneck are whitish with varying degrees of brown mottling; the back is generally dark grayish brown; the chest has patchy brown and white mottling; and the remiges and rectrices are dark brown to black (Johnsgard 1993; Dorr et al. 2014).

There is extensive individual variation in the immature-subadult plumage (Dorr et al. 2014). Although poorly described, subadult plumage is generally darker than juvenile plumage. The throat, foreneck, and chest are typically dull brown or tan; the head and back are usually a mixture of brown and black, and if nuptial crests occur, they are very small. The wing coverts are buff or slate gray with brown or black margins (retained from the juvenile plumage). Some individuals acquire definitive adult plumage by the second year, a few shortly after 1 year, but many after 2 years of age (Johnsgard 1993; Dorr et al. 2014).

In the definitive pre-breeding adult plumage, the head, neck, lower back, chest and underparts are all black, with a dull greenish 
gloss; the upper back, scapulars, and wing coverts are brownish gray with thick black margins; and the remiges and rectrices are brownish black to black. The nuptial crests vary from white to entirely black in different lengths and densities, both within and among the five major North American breeding regions (Dorr et al. 2014). Post-breeding adult plumage is noted as being similar to the pre-breeding plumage, except that the ornamental crests are lost shortly after egg laying (Johnsgard 1993; Dorr et al. 2014).

The objective of this paper is to add our observations of adult cormorants reverting back to "subadult" plumage during the breeding season to the scientific literature base and to encourage future formal research on within-season plumage changes.

\section{Methods}

\section{Study Area}

We selected two geographically distinct cormorant breeding areas, located on opposite sides of Ontario, Canada, for study (Fig. 1). The study areas were: Lake of the Woods, near Kenora, in extreme western Ontario $\left(49^{\circ} 39^{\prime} 46.80^{\prime \prime} \mathrm{N}, 94^{\circ} 30^{\prime} 25.20^{\prime \prime} \mathrm{W}\right)$ and eastern Lake Ontario, near Kingston, in southeastern Ontario $\left(44^{\circ}\right.$ $\left.11^{\prime} 27.60^{\prime \prime} \mathrm{N}, 76^{\circ} 32^{\prime} 34.80^{\prime \prime} \mathrm{W}\right)$. Both areas consisted of ground-nesting cormorant colonies on a series of small islands within approximately $15 \mathrm{~km}$ of the corresponding cities listed above. The islands are composed of granite slabs and/or limestone outcroppings and ranged in size from 0.2 ha to 3 ha. The Lake of the Woods breeding area is composed of five islands: Manitou Island, Lemmon Island, an unnamed island north of Lemmon Island, Guano Rock and an unnamed island northeast of Bathe Island. The eastern Lake Ontario breeding area is composed of four islands: Snake Island, Pigeon Island, West Brothers Island and Scotch Bonnet Island.

\section{Banding}

Beginning in 2000 for eastern Lake Ontario and in 2002 for Lake of the Woods through 2008, we color banded over 7,500 pre-fledged cormorants (Chastant et al. 2014). Each year during June and July, we surrounded crèches of flightless cormorants that were close to fledging ( 30 days old) and captured individual young, then banded and released them immediately back into the crèche. We banded each cormorant, on separate legs, with a unique aluminum band and a fieldreadable, tri-laminate plastic color leg band bearing a unique, engraved, alpha-numeric code (Pro-touch Engraving, Inc.). We distributed the banding effort among the various islands according to colony size, with larger colonies receiving more effort.
Resighting

The primary objective of our research was to resight as many color bands as possible to construct an age matrix for a population dynamics study (Chastant et al. 2014). We conducted color-band resighting by scanning the legs of cormorants with binoculars and/ or a spotting scope. We collected observations from an elevated blind erected prior to nest construction, at a distance that did not cause disturbance to nesting birds $(\geq 20 \mathrm{~m})$. Blinds were located on the unnamed island north of Lemmon Island in Lake of the Woods and on Snake Island in eastern Lake Ontario. As each color band had a unique alpha-numeric-code, we could determine the age and natal colony of each resighted bird.

For both Lake of the Woods and eastern Lake Ontario during 2006 and 2007, we collected observations from the blind once a month over the course of the breeding season: in May during nest construction and initial egg laying, in June during late-incubation, in July just before chick fledging, and in September after fledging, during pre-migratory staging. In 2006, we spent a continuous interval of $24 \mathrm{hr}$ in the blind each visit, and conducted observations during periods of daylight. In 2007 , observations from the blind were extended to span $24 \mathrm{hr}$ of consecutive daylight over 2 days. In 2008, we conducted band resighting in Lake of the Woods only during the month of July, prior to banding, for 2 days as a consecutive 24-hr daylight period (Table 1). Due to our primary objective of resighting as many color bands as possible, formal data collected about plumage was minimal. When time allowed, we took notes on the birds' plumage and photographs through a scope with a digital camera.

\section{RESUlts}

While conducting colony observations for a population dynamics study (Chastant et al. 2014), we began to notice plumage changes in a large proportion (> 75\%) of the cormorants present in the colonies. Plumage changes occurred in all ages of cormorants, with varying degrees of intensity. In 2006, individuals we observed in May in full breeding plumage with a jet black chest, head and nuptial crests, were by July and September developing mottling on their chest and head. Three examples are included to illustrate this phenomenon: 1) 2-year old (Fig. 2A); 2) 6-year-old (Fig. 2B); and 3) 7-year-old (Fig. 2C). We observed the same colony-wide plumage change pattern again in 2007 and 2008. Of the 534 total individuals observed during the 3 years of our study, 30 were photographed multiple times 

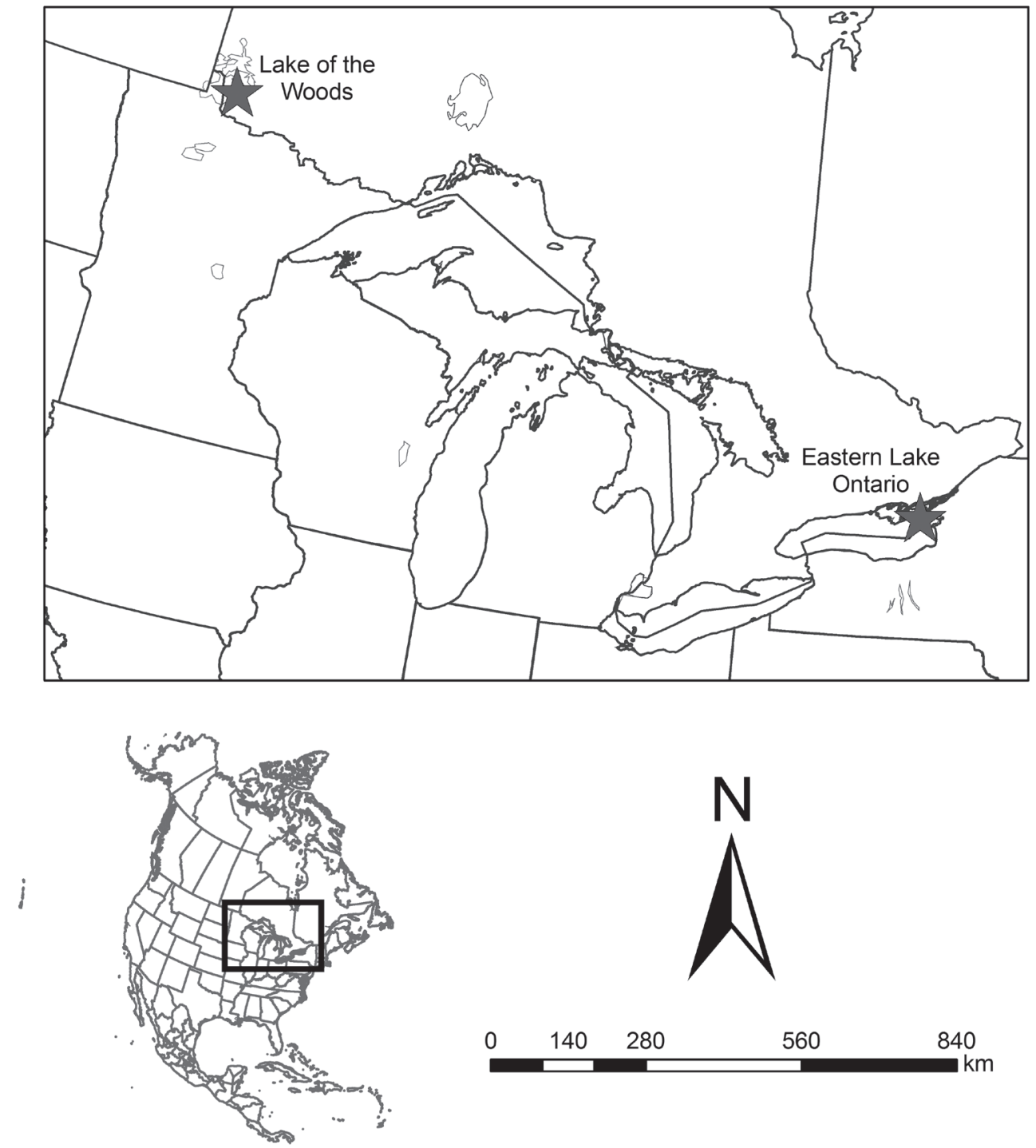

Figure 1. Location of two Double-crested Cormorant (Phalacrocorax auritus) breeding areas sampled for plumage characteristics during 2006-2008.

Table 1. Number of daylight hours spent observing Double-crested Cormorant (Phalacrocorax auritus) color bands from a blind in Lake of the Woods and eastern Lake Ontario, Canada, during the breeding seasons of 2006-2008.

\begin{tabular}{|c|c|c|c|c|c|c|c|c|c|}
\hline \multirow[b]{2}{*}{ Area } & \multicolumn{4}{|c|}{2006} & \multicolumn{4}{|c|}{2007} & \multirow{2}{*}{$\begin{array}{l}2008 \\
\text { July }\end{array}$} \\
\hline & May & June & July & Sept & May & June & July & Sept & \\
\hline Lake of the Woods & 18 & 19 & 17.5 & 13.5 & 24 & 24 & 24 & 24 & 24 \\
\hline Eastern Lake Ontario & 17 & 18 & 17 & 14 & 24 & 24 & 24 & 24 & $\mathrm{n} / \mathrm{a}$ \\
\hline
\end{tabular}




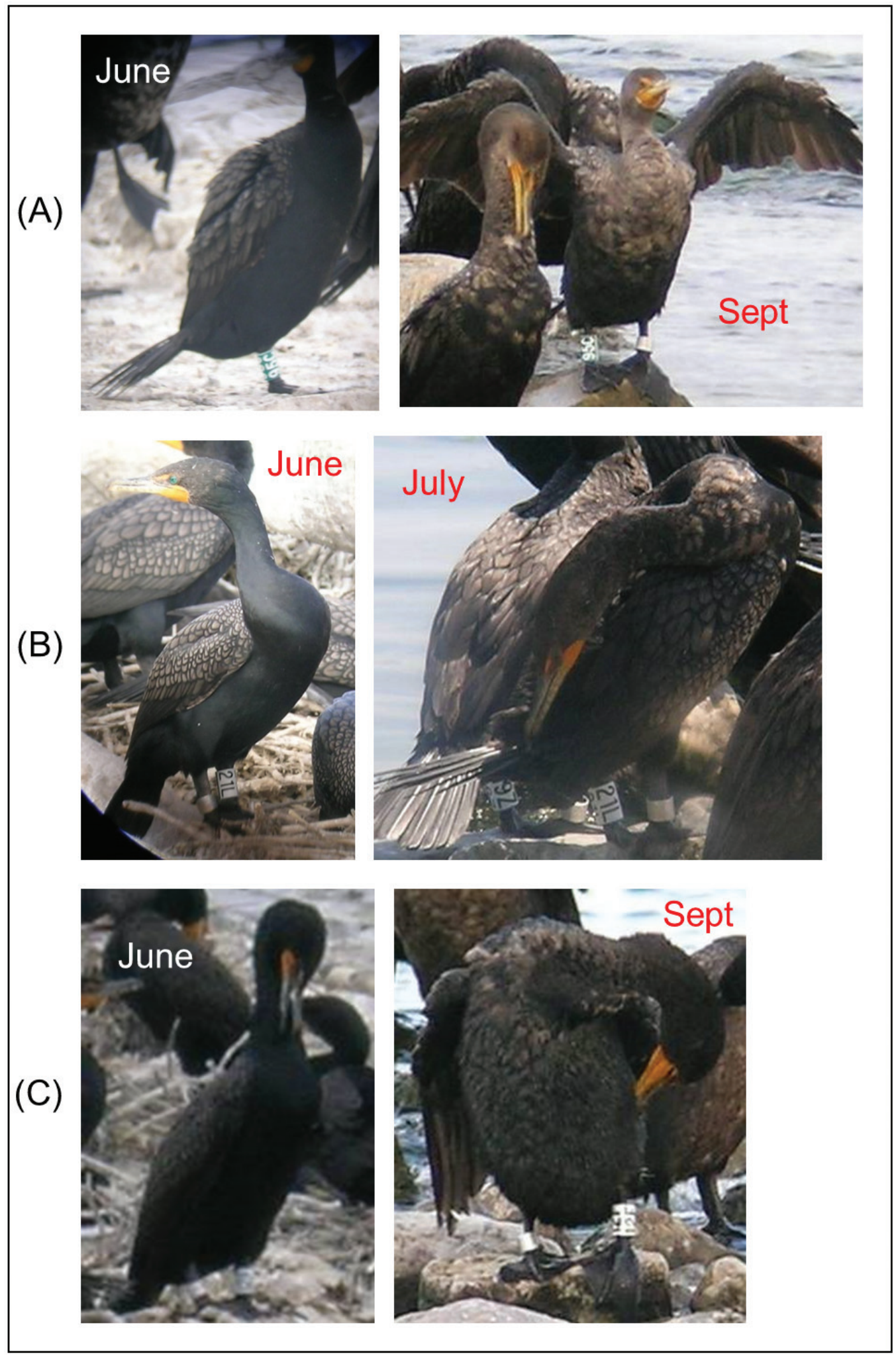

Figure 2. Within 2007 breeding season plumage change: (A) 2-year-old; (B) 6-year-old; and (C) 7-year-old Doublecrested Cormorant (Phalacrocorax auritus). 
throughout a nesting season to document the plumage change (Lake of the Woods = 14 of 210; eastern Lake Ontario $=16$ of 324).

\section{Discussion}

Since 1991, researchers have noticed that roughly $75 \%$ of the cormorants roosting at sites in the southeastern USA, during fall migration through mid-January, had juvenile/ subadult mottled plumage. But by mid-January, the roost would shift to $75 \%$ adult black plumage (D. T. King, pers. obs.). Satellite telemetry data from these roosting southeastern cormorants have revealed the summer/ breeding ranges include the Great Lakes and the Prairie Pothole Region of the Northern Great Plains in the USA (King et al. 2010). It was assumed that the age of the roost shifted, but in light of these new breeding ground observations, it may be inappropriate to age cormorants using plumage alone, especially during the winter months. The mechanism driving the observed cormorant plumage change is unknown, but sources of plumage change may include feather-degrading bacteria (Burtt and Ichita 2004; Goldenstein et al. 2004), food supply (Hill 1993; Fargallo et al. 2007), and testosterone levels (Stoehr and Hill 2001; Peters et al. 2006; Bokony et al. 2008). We present a groundwork of preliminary observation here; however, further investigation is needed to establish the source of the within-season plumage changes. These observations document an important but otherwise overlooked part of seasonal Double-crested Cormorant plumage variation, which may change the way cormorant and other waterbird research is conducted during the late- and non-breeding seasons.

\section{ACKNOWLEDGMENTS}

This project received support from multiple organizations, agencies, and individuals. We thank the technicians at the U.S. Department of Agriculture, Wildlife Services, National Wildlife Research Center, Mississippi field station for providing technical and logistics support and the Canadian Wildlife Service, the Ontario Ministry of Natural Resources, S. Elliott, S. Lockhart, J. McNulty, D. Moore, P. Rubens, and C. Weseloh for providing logistical and boat support. Thanks also to nu- merous volunteers for assistance in the field and the private landowners that granted access to the study sites. All applicable ethical guidelines for the use of birds in research have been followed, including those presented in the Ornithological Council's "Guidelines to the Use of Wild Birds in Research" (Fair et al. 2010). Colony work was conducted under the Institutional Animal Care and Use Committee approved U.S. Department of Agriculture, Wildlife Services, National Wildlife Research Center Study Protocol QA-979, U.S. Geological Survey bird banding lab permit 20873, and Canadian Wildlife Service bird banding permit 10431. Funding for this project was provided by the National Wildlife Research Center, Fort Collins, Colorado, USA.

\section{Literature Cited}

Bokony, V., L. Z. Garamszegi, K. Hirschenhauser and A. Liker. 2008. Testosterone and melanin-based black plumage coloration: a comparative study. Behavioral Ecology Sociobiology 62: 1229-1238.

Burtt, E. H., Jr. and J. M. Ichida. 2004. Gloger's rule, feather-degrading bacteria, and color variation among Song Sparrows. Condor 106: 681-686.

Chastant, J. E., D. T. King, D. V. C. Weseloh and D. J. Moore. 2014. Population dynamics of Double-crested Cormorants in two interior breeding areas. Journal of Wildlife Management 78: 3-11.

Dorr, B. S., J. J. Hatch and D. V. Weseloh. 2014. Doublecrested Cormorant (Phalacrocorax auritus), v. 2.0. In The Birds of North America (P. G. Rodewald, Ed.). Cornell Lab of Ornithology, Ithaca, New York. https://birdsna.org/Species-Account/bna/species/doccor, accessed 16 July 2017.

Fair, J., E. Paul and J. Jones (Eds.). 2010. Guidelines to the use of wild birds in research. Ornithological Council, Washington, D.C.

Fargallo, J. A., T. Laaksonen and E. K. K. Wakamatsu. 2007. A melanin-based trait reflects environmental growth conditions of nestling male Eurasian Kestrels. Evolutionary Ecology 21: 157-171.

Filardi, C. E. and S. Rohwer. 2001. Life history implications of complete and incomplete primary molts in Pelagic Cormorants. Condor 103: 555-569.

Galvan, I. 2004. Age-related spatial segregation of Great Cormorants in a roost. Waterbirds 27: 377-381.

Goldenstein, G., K. R. Flory, B. A. Browne, S. Majid, J. M. Ichida and E. H. Burtt, Jr. 2004. Bacterial degradation of black and white feathers. Auk 121: 656-659.

Hill, G. E. 1993. The proximate basis of inter- and intrapopulation variation in female plumage coloration in the House Finch. Canadian Journal of Zoology 71: 619-627.

Johnsgard, P. A. 1993. Cormorants, darters, and pelicans of the world. Smithsonian Institution Press, Washington, D.C.

King, D. T., J. F. Glahn and K. J. Andrews. 1995. Daily activity budgets and movements of winter roosting Double-crested Cormorants determined by biotelemetry in the Delta region of Mississippi. Colonial Waterbirds 18 (Special Publication 1): 152-157. 
King, D. T., B. F. Blackwell, B. S. Dorr and J. L. Belant. 2010. Effects of aquaculture on migration and movement patterns of Double-crested Cormorants. Human-Wildlife Conflicts 4: 66-75.

Morrison, M. L., R. D. Slack and E. Shanley, Jr. 1978. Age and foraging ability relationships of Olivaceous Cormorants. Wilson Bulletin 90: 414-422.

Peters, A., K. Delhey, W. Goymann and B. Kempenaers. 2006. Age-dependent association between testosterone and crown UV coloration in male Blue Tits $(\mathrm{Pa}$ rus caeruleus). Behavioral Ecology and Sociobiology 59: 666-673.
Rasmussen, P. C. 1987. Molts of the Rock Shag and new interpretations of the plumage sequence. Condor 89: 760-766.

Rasmussen, P. C. 1988. Variation in the juvenal plumage of the Red-legged Shag (Phalacrocorax gaimardi) and notes on behavior of juveniles. Wilson Bulletin 100: 535-544.

Stoehr, A. M. and G. E. Hill. 2001. The effects of elevated testosterone on plumage hue in male House Finches. Journal of Avian Biology 32: 153-158. 